\title{
Mercury and Antibiotic Resistance Co-Selection in Bacillus sp. Isolates from the Almadén Mining District
}

\author{
Marina Robas*D, Agustín Probanza (D), Daniel González (D) and Pedro A. Jiménez \\ Department of Pharmaceutical and Health Sciences, Universidad San Pablo CEU, \\ 28668 Boadilla del Monte, Spain; a.probanza@ceu.es (A.P.); daniel.gonzalezreguero@ceu.es (D.G.); \\ pedro.jimenezgomez@ceu.es (P.A.J.) \\ * Correspondence: marina.robasmora@ceu.es; Tel.: +34-620-25-81-84
}

check for

updates

Citation: Robas, M.; Probanza, A.; González, D.; Jiménez, P.A. Mercury and Antibiotic Resistance

Co-Selection in Bacillus sp. Isolates from the Almadén Mining District. Int. J. Environ. Res. Public Health 2021, 18, 8304. https://doi.org/10.3390/ ijerph18168304

Academic Editors: Sebastian Gnat and Aneta Nowakiewicz

Received: 5 June 2021

Accepted: 4 August 2021

Published: 5 August 2021

Publisher's Note: MDPI stays neutral with regard to jurisdictional claims in published maps and institutional affiliations.

Copyright: (c) 2021 by the authors. Licensee MDPI, Basel, Switzerland. This article is an open access article distributed under the terms and conditions of the Creative Commons Attribution (CC BY) license (https:// creativecommons.org/licenses/by/ $4.0 /)$.

\begin{abstract}
Antibiotic resistance (AR) in the environment is of great global concern and a threat to public health. Soil bacteria, including Bacillus spp., could act as recipients and reservoirs of AR genes of clinical, livestock, or agricultural origin. These genes can be shared between bacteria, some of which could be potentially human pathogens. This process can be favored in conditions of abiotic stress, such as heavy metal contamination. The Almadén mining district (Ciudad Real, Spain) is one of the environments with the highest mercury $(\mathrm{Hg})$ contamination worldwide. The link between heavy metal contamination and increased AR in environmental bacteria seems clear, due to co-resistance and co-selection phenomena. In the present study, 53 strains were isolated from rhizospheric and bulk soil samples in Almadén. AR was tested using Vitek ${ }^{\circledR} 2$ and minimum inhibitory concentration (MIC) values were obtained and interpreted based on the criteria of the Clinical and Laboratory Standards Institute (CLSI) guidelines. Based on the resistance profiles, five different antibiotypes were established. The $\mathrm{Hg}$ minimum bactericidal concentration (MBC) of each strain was obtained using the plating method with increasing concentrations of $\mathrm{HgCl} 2$. A total of $72 \%$ of Bacillus spp. showed resistance to two or more commonly used antibiotics. A total of 38 isolates expressed AR to cephalosporins. Finally, the environmental co-selection of AR to cephalosporins and tetracyclines by selective pressure of $\mathrm{Hg}$ has been statistically demonstrated.
\end{abstract}

Keywords: Bacillus; antibiotic resistance; mercury resistance; resistance co-selection; soil contamination

\section{Introduction}

Antibiotic resistance (AR) of an environmental origin has been attracting the attention of numerous studies in recent years. Its development and evolution in the clinical setting seems to be increasingly evident [1-4]. Numerous AR genes found in pathogenic bacteria have evolved or have been acquired from environmental microbial communities [5], which suggests the need to study and understand how the environment (soils, waters, sediments, etc.) can be reservoirs of AR. Bacteria that are resistant to antibiotics of clinical importance such as aminoglycosides, $\beta$-lactams, glycopeptides, macrolides, quinolones, streptogramin, tetracyclines, and trimethoprim/sulfamethoxazole have been reported [1,3]. Likewise, multidrug-resistant bacteria have also been reported to be common in the environment [6]. For this reason, the World Health Organization (Geneva, Switzerlan) has stated that AR genes are a new pollutant due to their emerging prevalence and extensive distribution [7].

As with AR, it is common to find microorganisms resistant to heavy metals in the natural environment. This resistance is a common phenotype in those microorganisms that have been exposed to metals in their habitats [8].

A good example of an area that is highly contaminated by heavy metals is the Almadén mining district in Ciudad Real, Castilla y León, Spain. The size of the area is approximately $300 \mathrm{~km}^{2}$, and it is of geological interest worldwide. Together with the Idrija mine in Slovenia [9], Almadén is considered to have one of the largest deposits of mercury $(\mathrm{Hg})$, with high geogenic levels of $\mathrm{Hg}$ as well. The concentration of this heavy metal in the 
Almadén soil exceeds $106 \mu \mathrm{g} / \mathrm{kg}$ [10]. Mineral $\mathrm{Hg}$ deposits are found predominantly as cinnabar $(\mathrm{HgS})$. Elemental $\mathrm{Hg}(\mathrm{Hg} 0)$ is also present and abundant in the local atmosphere, where it can remain for up to 1.7 years [11]. Given Almadén's large size, as well as the $\mathrm{Hg}$ dispersion by rivers and emissions throughout its 2000 years of mining activity, it is considered one of the most contaminated areas on the planet, due to the natural origin of $\mathrm{Hg}$ in addition to its anthropogenic exploitation. When the mine closed in 2003, other forms of land use had to be considered, such as agriculture and livestock. However, until economically and environmentally viable strategies are achieved to reduce soil $\mathrm{Hg}$ contamination, these productive soil activities cannot be carried out safely.

$\mathrm{Hg}$ is a toxic metal, which means that it does not have a specific biological role and its introduction into the body is unnecessary. Therefore, at certain doses $\mathrm{Hg}$ produces adverse effects, such as problems with development, growth, and reproduction of living beings [12]. Moreover, this heavy metal has the potential for bioaccumulation and biomagnification, which can be transmitted through the trophic chain, thereby affecting human health [13]. The use of this metal is currently controlled at the European level by Regulation (EU) 2017/852 regarding mercury and, since 2013, following the legally binding UN Convention of Minamata, it has been recognized as a global pollutant [14].

The increase in AR genes is considered to be a consequence of the massive use of antibiotics in medical treatment and agriculture [15,16]. However, evidence shows that the spread of AR genes can also be influenced by heavy metal contamination [17,18]. As early as the 1970's, it was discovered that heavy metal resistance (HMR) and AR can be selected simultaneously in the ecosystem of heavy metal pollutants [19]. At the molecular level, co-selection occurs when two or more genetically linked resistance genes are together, and cross-selection refers to a single genetic element providing tolerance to more than one antimicrobial agent [20]. Among all heavy metals, co-selection of AR and HMR seems most noticeable in the presence of $\mathrm{Hg}$. Resistance genes seem to be highly connected with plasmids, transposons, and integron-associated integrases [21]. This frequent linkage between $\mathrm{Hg}$ resistance and $\mathrm{AR}$ has been documented in bacteria from a wide range of habitats, including mine sediments [22], freshwater microcosms [23], agriculture soil [24], wastewater treatment systems [25], and water sediment [26]. However, bacterial communities are shaped by a complex series of evolutionary, ecological, and environmental factors [24]. The patterns of HMR and AR genes in an area with long-term contamination by heavy metals have hardly been studied [8], especially in bacterial genera that are predominantly environmental and scarcely associated with a clinical setting, since they do not display pathogenic potential. This is the case of the Bacillus genus, which is rarely associated with the appearance of diseases in humans and animals, except for B. anthracis, B. thuringiensis, B. sphaericus, and B. cereus.

All members of the Bacillus spp. are Gram-positive, endospore-forming bacilli. The latter enhance cell viability, even under conditions of high heavy metal pressure. The Bacillus genus is known to produce a wide variety of antimicrobial compounds. This leads to the development of AR genes and different resistance strategies against the drugs that they themselves produce. Furthermore, other environmental bacteria may have developed resistance mechanisms due to their exposure to antibiotics produced by Bacillus present in the same environmental niche [25]. With the aforementioned in mind, the environment in general and the soil in particular, seem to be reservoirs of AR genes [27]. These AR genes have the capability of spreading and being transmitted through ecosystems. Moreover, they can be acquired by pathogens that are capable of affecting human health [28]. For this reason, there is growing interest in determining not only the soil antibiotic resistome (comprising all AR genes and their precursors) [29], but also those bacteria that can co-select AR genes in environments with high selective pressure. This bacterial ability for gene co-selection and transmission may pose a risk of dissemination through soil management and ecological processes [28,30] to human pathogens [31,32]. Expanding this knowledge will allow us not only to prioritize the inherent risk to public health, but also to enable the development of appropriate control measures. 
The present study aims to analyze the possible co-selection of AR and HMR in the Bacillus genus by studying rhizospheric strains isolated from the Almadén mining district, which has been subjected to long-term $\mathrm{Hg}$ contamination.

\section{Materials and Methods}

\subsection{Obtaining Mercury-Tolerant Strains}

This study was carried out using rhizospheric and bulk soil samples obtained from an abandoned metallurgical plant in the mining district of Almadén in Ciudad Real, Spain. Experimental "Plot $\mathrm{M}$ " is classified as an area with a high level of $\mathrm{Hg}$ contamination of up to $1710 \mathrm{mg} / \mathrm{kg} \mathrm{Hg}$ [33]. The plants sampled were Rumex induratus Boiss. \& Reut. (A), Rumex bucephalophorus L. (B), Avena sativa L. (C), Medicago sativa L. (D), and Vicia benghalensis L. (E). Bulk soil samples were taken from the same plot, in an area free of vegetation. In all cases, the samples were collected in quadruplicate, within the same plot, in order to achieve sufficient mass for this and other assays. For this study, the content of the replicas of each rhizosphere/bulk soil was homogenized until reaching a mass of not less than $2.5 \mathrm{~g}$. For the extraction of bacterial communities, the modified method described by García-Villaraco et al. [34] was employed, suspending $2 \mathrm{~g}$ of sample in $20 \mathrm{~mL}$ of sterile saline solution $(\mathrm{NaCl} 0.45 \%)$, stirring with blades at $16,000 \mathrm{rpm}$ for $2 \mathrm{~min}$ to achieve homogenization. The mixture was then centrifuged at $2500 \times g$ r.p.m. for $10 \mathrm{~min}$.

The isolation of $\mathrm{Hg}$-resistant bacteria was carried out by mass seeding $(1 \mathrm{~mL}$ of the supernatant) on Standard Methods Agar plates (SMA, Condalab ${ }^{\circledR}$, Torrejón de Ardoz, Spain) supplemented with $40 \mu \mathrm{g} / \mathrm{mL}$ of $\mathrm{HgCl}_{2}$. Bacterial isolates that met Mathema criteria [35] for Gram-positive minimum bactericidal concentration (Hg MBC $\geq 40 \mu \mathrm{g} / \mathrm{mL}$ ) were considered to be resistant to $\mathrm{Hg}$ and selected for further analysis.

\subsection{Molecular Identification of Microorganisms}

For the isolation of bacterial DNA, a colony was taken from the pure culture plate grown in SMA and suspended in $100 \mu \mathrm{L}$ of $1 \times$ PBS. The Nucleo spin Gel and PCR clean up ${ }^{\circledR}$ Kit (Machery-Nagel, Strasbourg, France) was used to purify PCR products. A PCR was performed with the MultiGene Mini ${ }^{\circledR}$ kit (Labnet, Madrid, Spain) of a $16 \mathrm{~S}$ ssrRNA fragment with the primers fD1 5'-GAGTTTGATCCTGGCTCA-3' and rP2 (5'ACGGCTACCTTGTTACGACTT-3') [36]. Ready to go ${ }^{\circledR}$ PCR beads (Healthcare) were used for amplification. For purification of that which was amplified, the Nucleo spin Gel and PCR clean up ${ }^{\circledR}$ Kit was used and the concentration and purity of DNA was measured with DropVue $^{\circledR}$ (General Electric, USA). The sequencing of the PCR products was carried out in the Genomics department at Complutense University of Madrid following the method of Sanger et al. [37] with a 3730xl DNA Analyzer ${ }^{\circledR}$ sequencer (Applied Biosystems, USA). Organisms were identified by comparative bioinformatic analysis with the CLC Sequence Viewer 7 program, and the sequences were aligned with the Nucleotide Massagery tool and EMBL-EBI, Clustal Omega. The consensus sequence (1200 bp) was compared to BLAST from NCBI.

\subsection{Microbial Diversity}

For each of the rhizospheric and bulk soil samples described in 2.1, the microbial diversity was analyzed by calculating the Shannon-Wiener index $\left(H^{\prime}\right)$ (bits/ind) [38] according to the following formula:

$$
H^{\prime}=-\sum_{i=1}^{s}\left(\left(\frac{n_{i}}{n}\right) \times \log _{2}\left(\frac{n_{i}}{n}\right)\right)
$$

$H^{\prime}=$ Shannon-Wiener index.

$S=$ total number of species.

$n_{i}=$ number of individuals in a population (species). 
$p_{i}=$ proportional abundance of the $i t h$ species:

$$
p_{i}=\frac{n_{i}}{N}
$$

$N=$ total number of individuals in " $S$ " population.

In addition, the Pielou index $\left(J^{\prime}\right)$ [39] was calculated to determine the species evenness. $J^{\prime}$ is constrained between 0 and $100(\%)$ and is calculated using the following formula:

$$
J^{\prime}=\frac{H^{\prime}}{H_{\max }} \times 100
$$

where $H_{\max }$ (bits / ind) is the maximum diversity that would be obtained if the distribution of the abundances of the species in the community were perfectly equitable, and is calculated as follows:

$$
H_{\text {max }}=\log _{2} S
$$

\subsection{Hg Minimum Bactericidal Concentration (MBC)}

To study the $\mathrm{Hg} \mathrm{MBC}$ of the selected bacterial strains (those that necessarily met the $\mathrm{MBC}$ mercurotolerance criteria $\mathrm{Hg} \mathrm{MBC} \geq 40 \mu \mathrm{g} / \mathrm{mL}$ and belonged to the Bacillus genus), a Müller Hinton agar (Condalab ${ }^{\circledR}$ ) was sown in the following $\mathrm{HgCl}_{2}$ concentrations: 400, 350, $200,175,150,100,87.5,75,50$, and $43.75 \mu \mathrm{g} / \mathrm{mL}$. The MBC value corresponds to the lowest concentration of $\mathrm{HgCl}_{2}$ capable of inhibiting the growth of more than $99.9 \%$ of the bacteria.

\subsection{Antibiogram and Antibiotic Minimum Inhibitory Concentration (MIC)}

Inoculum, seeding, and incubation of the AST-ST01 card of the Vitek ${ }^{\circledR} 2$ system were carried out in accordance with the manufacturer's specifications (BioMérieux ${ }^{\circledR}$ ). The data obtained were interpreted according to the guidelines entitled "Performance Standards for Antimicrobial Susceptibility Testing" (CLSI, 2017) [40] and "The European Committee on Antimicrobial Susceptibility Testing. Breakpoint tables for interpretation of MICs and zone diameters" (EUCAST, 2021) [41]. Since there are no generic values for Bacillus spp., the values of Bacillus antrhacis were used for all strains belonging to this genus.

\subsection{Statistical Analysis}

In order to study the possible correlation between the MIC of the tested antibiotics and the $\mathrm{Hg} \mathrm{MBC}$, a linear regression analysis was carried out between the tested antibiotics and the MBC values for each of the studied strains. The statistical program SPSS v.19.0 (SPSS inc.) was used. Significant differences between the values exist when $p$-value $\leq 0.05$.

\section{Results}

A total of 149 strains were isolated from bulk soil and the rhizosphere of local plants of the Almadén mining district ("Plot M"). A total of 97 resulted to be Gram positive. Among these, those belonging to the Bacillus spp. were selected, making a total of 53 isolates. Figure 1 shows the complete information of the isolated strains, including the origin of isolation and the calculation of the diversity of each sample (rhizosphere of the plant or bulk soil). 


\begin{tabular}{|c|c|c|c|c|c|c|}
\hline Acronym & $\begin{array}{l}\text { Source } \\
\text { Bulk soil/ Plant species }\end{array}$ & Bacterial spp. & $\begin{array}{l}\text { Number of bacterial } \\
\text { species per sample } \\
\qquad(N=53)\end{array}$ & $\begin{array}{c}\mathbf{H}^{\prime} \\
\text { (bits/ ind) }\end{array}$ & $\begin{array}{c}\text { Hmax } \\
\text { (bits/ ind) }\end{array}$ & $\begin{array}{c}\mathrm{J}^{\prime} \\
(\%)\end{array}$ \\
\hline SL & Bulk soil & $\begin{array}{l}\text { B. circulans } \\
\text { B. niacini } \\
\text { B. toyonensis }\end{array}$ & $\begin{array}{l}\mathrm{n}=1 \\
\mathrm{n}=1 \\
\mathrm{n}=8\end{array}$ & 0.92 & 1.58 & $58 \%$ \\
\hline $\mathrm{A}$ & Rumex induratus & $\begin{array}{l}\text { B. aryabhattai } \\
\text { B. megaterium } \\
\text { B. niacini } \\
\text { B. toyonensis }\end{array}$ & $\begin{array}{l}\mathrm{n}=4 \\
\mathrm{n}=3 \\
\mathrm{n}=1 \\
\mathrm{n}=5\end{array}$ & 1.83 & 2.00 & $91 \%$ \\
\hline B & Rumex bucephalophorus & $\begin{array}{l}\text { B. bataviensis } \\
\text { B. deserti } \\
\text { B. nealsonii } \\
\text { B. niacini } \\
\text { B. toyonensis }\end{array}$ & $\begin{array}{l}\mathrm{n}=1 \\
\mathrm{n}=1 \\
\mathrm{n}=1 \\
\mathrm{n}=1 \\
\mathrm{n}=1\end{array}$ & 2.32 & 2.32 & $100 \%$ \\
\hline C & Avena sativa & $\begin{array}{l}\text { B. aryabhattai } \\
\text { B. simplex } \\
\text { B. thuringiensis } \\
\text { Bacillus spp. }\end{array}$ & $\begin{array}{l}\mathrm{n}=3 \\
\mathrm{n}=1 \\
\mathrm{n}=1 \\
\mathrm{n}=1\end{array}$ & 1.79 & 2.00 & $90 \%$ \\
\hline $\mathrm{D}$ & Medicago sativa & $\begin{array}{l}\text { B. drentensis } \\
\text { B. ginsengisoli } \\
\text { B. thuringiensis } \\
\text { B. toyonensis } \\
\text { Bacillus spp. }\end{array}$ & $\begin{array}{l}\mathrm{n}=2 \\
\mathrm{n}=1 \\
\mathrm{n}=3 \\
\mathrm{n}=1 \\
\mathrm{n}=1\end{array}$ & 2.16 & 2.32 & $93 \%$ \\
\hline E & Vicia benghalensis & $\begin{array}{l}\text { B. aryabhattai } \\
\text { B. drentensis } \\
\text { B. nealsonii } \\
\text { B. niacini } \\
\text { B. vireti } \\
\text { Bacillus spp. }\end{array}$ & $\begin{array}{l}\mathrm{n}=1 \\
\mathrm{n}=4 \\
\mathrm{n}=2 \\
\mathrm{n}=2 \\
\mathrm{n}=1 \\
\mathrm{n}=1\end{array}$ & 2.50 & 2.58 & $97 \%$ \\
\hline
\end{tabular}

Figure 1. Isolated Bacillus spp. strains and diversity of the analyzed samples. $\mathrm{H}^{\prime}$ : diversity calculated using the ShannonWiener index (bits/ind), $\mathrm{H}_{\max }$ : maximum diversity (bits/ind), and $\mathrm{J}^{\prime}$ : Pielou index (\%).

Figure 2 shows the results of the antibiogram performed with the automated Vitek ${ }^{\circledR}$ 2 technique, including both MIC breakpoints (Figure 2A) and the interpretation of the breakpoints according to the CLSI guideline criteria (Figure 2B). Bacterial isolates were grouped based on their MICs against different antibiotics into five antibiotypes. Antibiotypes I and Ib are practically the same and include profiles with AR to : $\hat{A}$-lactams and sulfamides. In addition, Ib includes profiles with high MIC to tetracyclines. Antibiotypes II and III correspond to the phenotypes most similar to the wild type. The difference between the two is essentially that antibiotype III includes intermediate AR values for ceftriaxone. Finally, antibiotype IV includes those strains with high profiles of AR to cephalosporins and sulfa drugs.

Figure 3 additionally includes information related to $\mathrm{Hg} \mathrm{MBC}$, which ranges in values between $75 \mu \mathrm{g} / \mathrm{mL}$ and $200 \mu \mathrm{g} / \mathrm{mL}$, being the most frequent mean value $80 \mu \mathrm{g} / \mathrm{mL}$ and $100 \mu \mathrm{g} / \mathrm{mL}$. In this way, each species with a certain tolerance to $\mathrm{Hg}(\mathrm{MBC})$ is related to the antibiotype to which it belongs. Likewise, the frequency (n) with which species appear sharing these characteristics is included. The most common phenotype $(\mathrm{n}=11)$. Is clearly that of Bacillus toyonensis with a $\mathrm{Hg} \mathrm{MBC}$ of $80 \mu \mathrm{g} / \mathrm{mL}$ and belonging to antibiotype I. 
A) MIC values

\begin{tabular}{|c|c|c|c|c|c|c|c|c|c|c|c|c|c|}
\hline Antibiotypes & $N=53$ & $\mathrm{SL}$ & $\begin{array}{c}\text { Plant } \\
\text { rhizosp. }\end{array}$ & ВCP & AMP & CTX & CRO & CLI & VAN & TCY & SXT & ERI & LVX \\
\hline $\mathrm{I}$ & $\mathrm{n}=29$ & $\mathrm{n}=9$ & $\mathrm{n}=20$ & $\geq 8$ & $\geq 16$ & 8 & $\geq 8$ & $\geq 1$ & $0.5-1$ & $0.5-8$ & $10-160$ & $0.12-0.5$ & $\leq 0.25$ \\
\hline $\mathrm{Ib}$ & $\mathrm{n}=4$ & $\mathrm{n}=0$ & $\mathrm{n}=4$ & $\geq 8$ & $\geq 16$ & 8 & $\geq 8$ & $\geq 1$ & 1 & $\geq 16$ & $40-80$ & $\leq 0.12$ & $\leq 0.25$ \\
\hline II & $\mathrm{n}=9$ & $\mathrm{n}=0$ & $\mathrm{n}=9$ & $0.06-1$ & $0.25-0.5$ & $\leq 0.12$ & $\leq 0.12$ & $\geq 1$ & $\leq 0.12$ & $0.5-2$ & oct- 40 & $0.12-0.25$ & $\leq 0.25$ \\
\hline III & $\mathrm{n}=6$ & $\mathrm{n}=0$ & $\mathrm{n}=6$ & $\leq 0.06$ & $\leq 0.25$ & 4 & 4 & $\geq 1$ & $\leq 0.12$ & $\leq 0.25$ & $\leq 10$ & $\leq 0.12$ & $\leq 0.25$ \\
\hline IV & $\mathrm{n}=5$ & $\mathrm{n}=1$ & $\mathrm{n}=4$ & $0.06-0.25$ & $\leq 0.25$ & 8 & $\geq 8$ & $0.5-1$ & $\leq 0.12$ & $\leq 0.25$ & oct-20 & $0.12-0.5$ & $\leq 0.25$ \\
\hline \multicolumn{14}{|c|}{ B) Susceptibility interpretation } \\
\hline Antibiotypes & $N=53$ & SL & $\begin{array}{c}\text { Plant } \\
\text { rhizosp. }\end{array}$ & ВCP & AMP & CTX & CRO & CLI & VAN & TCY & SXT & ERI & LVX \\
\hline $\bar{I}$ & $\mathrm{n}=29$ & $\mathrm{n}=9$ & $\mathrm{n}=20$ & $\bar{R}$ & $R$ & $R$ & $\bar{R}$ & $S$ & $S$ & $S$ & $\bar{R}$ & $S$ & $S$ \\
\hline $\mathrm{lb}$ & $\mathrm{n}=4$ & $\mathrm{n}=0$ & $\mathrm{n}=4$ & $\mathrm{R}$ & $\mathrm{R}$ & $\mathrm{R}$ & $\mathrm{R}$ & S & S & $\mathrm{R}$ & $\mathrm{R}$ & S & S \\
\hline II & $\mathrm{n}=9$ & $\mathrm{n}=0$ & $\mathrm{n}=9$ & S & S & S & S & S & S & S & $\mathrm{R}$ & S & S \\
\hline III & $\mathrm{n}=6$ & $\mathrm{n}=0$ & $\mathrm{n}=6$ & S & S & S & I & S & S & S & $\mathrm{R}$ & S & S \\
\hline IV & $\mathrm{n}=5$ & $\mathrm{n}=1$ & $\mathrm{n}=4$ & S & $S$ & $\mathrm{R}$ & $\mathrm{R}$ & $S$ & $S$ & $S$ & $\mathrm{R}$ & $S$ & $S$ \\
\hline
\end{tabular}

Figure 2. Antibiotic susceptibility of the Bacillus strains. SL: Bacillus spp. strains isolated from bulk soil. Plant rhizosph.: Bacillus spp. strains isolated from assayed plant rhizospheres. Antibiotics included on the Vitek ${ }^{\circledR} 2$ AST-ST01 card $(\mu \mathrm{g} / \mathrm{mL})$ : BCP: benzylpenicillin, CTX: cefotaxime, AMP: ampicillin, CRO: ceftriaxone, LVX: levofloxacin, TCY: tetracycline, ERI: erythromycin, VAN: vancomycin, CLI: clindamycin, LIN: linezolid, SXT: cotrimoxazole. (A) MIC values for each of the antibiotics tested against the set of 53 Bacillus isolates, and (B) breakpoint interpretation according to CLSI and EUCAST guidelines for each tested antibiotic. R: resistant, I: intermediate, S: susceptible.

\begin{tabular}{|c|c|c|c|c|c|c|c|}
\hline Identification & $\begin{array}{c}\mathrm{MBC} \mathrm{Hg}^{2+} \\
(\mu \mathrm{g} / \mathrm{mL})\end{array}$ & Antibiotype & $\begin{array}{c}\text { Numer of } \\
\text { isolates } \\
(\mathrm{N}=53)\end{array}$ & Identification & $\begin{array}{c}\mathrm{MBC} \mathrm{Hg}^{2+} \\
(\mu \mathrm{g} / \mathrm{mL})\end{array}$ & Antibiotype & $\begin{array}{l}\text { Numer of } \\
\text { isolates } \\
(\mathrm{N}=53)\end{array}$ \\
\hline B. toyonensis & 75 & I & $\mathrm{n}=1$ & B. niacini & 150 & I & $\mathrm{n}=1$ \\
\hline Bacillus spp. & 80 & I & $\mathrm{n}=2$ & B. toyonensis & 150 & I & $\mathrm{n}=1$ \\
\hline B. ginsengisoli & 80 & I & $\mathrm{n}=1$ & B. aryabhattai & 150 & I & $\mathrm{n}=1$ \\
\hline B. toyonensis & 80 & I & $n=11$ & B. megaterium & 150 & I & $\mathrm{n}=1$ \\
\hline B. niacini & 100 & I & $\mathrm{n}=1$ & B. drentensis & 170 & I & $\mathrm{n}=1$ \\
\hline B. thuringiensis & 100 & I & $\mathrm{n}=1$ & B. aryabhattai & 175 & I & $\mathrm{n}=1$ \\
\hline B. drentensis & 100 & I & $\mathrm{n}=1$ & B. thuringiensis & 175 & I & $\mathrm{n}=1$ \\
\hline Bacillus spp. & 100 & I & $\mathrm{n}=1$ & B. niacini & 200 & I & $\mathrm{n}=1$ \\
\hline B. megaterium & 100 & I & $\mathrm{n}=1$ & B. nealsonii & 150 & $\mathrm{Ib}$ & $\mathrm{n}=1$ \\
\hline B. thuringiensis & 100 & I & $\mathrm{n}=1$ & B. toyonensis & 175 & $\mathrm{Ib}$ & $\mathrm{n}=1$ \\
\hline Identification & $\begin{array}{c}\mathrm{MBC} \mathrm{Hg}^{2+} \\
(\mu \mathrm{g} / \mathrm{mL})\end{array}$ & Antibiotype & $\begin{array}{c}\text { Numer of } \\
\text { isolates } \\
(\mathrm{N}=53)\end{array}$ & Identification & $\begin{array}{c}\mathrm{MBC} \mathrm{Hg}^{2+} \\
(\mu \mathrm{g} / \mathrm{mL})\end{array}$ & Antibiotype & $\begin{array}{c}\text { Numer of } \\
\text { isolates } \\
(\mathrm{N}=53)\end{array}$ \\
\hline B. aryabhattai & 200 & $\mathrm{Ib}$ & $\mathrm{n}=1$ & B. megaterium & 87.5 & III & $\mathrm{n}=1$ \\
\hline B. aryabhattai & 87.5 & II & $\mathrm{n}=2$ & B. nealsonii & 87.5 & III & $\mathrm{n}=1$ \\
\hline B. niacini & 87.5 & II & $\mathrm{n}=1$ & B. vireti & 150 & III & $n=1$ \\
\hline B. bataviensis & 100 & II & $\mathrm{n}=1$ & B. circulans & 50 & & $\mathrm{n}=1$ \\
\hline B. aryabhattai & 100 & II & $\mathrm{n}=1$ & B. niacini & 100 & & $\mathrm{n}=1$ \\
\hline B. drentensis & 100 & II & $\mathrm{n}=1$ & B. nealsonii & 100 & & $\mathrm{n}=1$ \\
\hline B. aryabhattai & 150 & II & $\mathrm{n}=1$ & B. aryabhattai & 175 & & $\mathrm{n}=1$ \\
\hline B. simplex & 150 & II & $\mathrm{n}=1$ & B. thuringiensis & 175 & & $\mathrm{n}=1$ \\
\hline B. deserti & 150 & II & $\mathrm{n}=1$ & & & & \\
\hline B. drentensis & 75 & III & $\mathrm{n}=3$ & & & & \\
\hline
\end{tabular}

Figure 3. Arrangements between $\mathrm{Hg} \mathrm{MBC}$ and antibiotypes. n: number of isolates in each situation. MBC: minimum bactericidal concentration. 
The possible correlation between $\mathrm{Hg}$ resistance and AR was analyzed using a linear regression (Table 1). Those antibiotics showing significant differences between MIC and MBC variables are indicated with an asterisk $\left(^{*}\right)$. In these cases, the MIC of the tested antibiotics covariated with the Hg MBC. Although levofloxacin was tested, the p-value does not appear in the table since all the strains had the same MIC value and was interpreted as a constant in the analysis.

Table 1. Co-selection of $\mathrm{Hg} \mathrm{MBC}$ and $\mathrm{AR}$ in the isolated Bacillus spp. strains.

\begin{tabular}{|c|c|c|}
\hline Family & Antibiotic & $p$-Value \\
\hline \multirow{4}{*}{ Betalactams } & benzylpenicillin & 0.597 \\
\hline & ampicillin & 0.992 \\
\hline & cefotaxime & $0.035 *$ \\
\hline & ceftriaxone & $0.038 *$ \\
\hline Lincosamines & clindamycin & 0.051 \\
\hline Glycopeptides & vancomycin & 0.988 \\
\hline Tetracyclines & tetracycline & $0.001 *$ \\
\hline Sulfamides & cotrimoxazole & 0.322 \\
\hline Macrolides & erythromycin & 0.289 \\
\hline Quinolones & levofloxacin & - \\
\hline
\end{tabular}

\section{Discussion}

Of the 149 total bacterial strains isolated from the bulk soil and rhizosphere of plants naturally grown in the soil of the Almadén mining district, 65\% were identified as Grampositive bacilli. Of the latter, more than half (54\%) were identified as different Bacillus spp species. This is something that other authors had already achieved while working with Hgcontaminated soils [42,43], including members of the species B. thuringiensis, B. megaterium, and others that are less common, such as B. drentensis, B. bataviensis, and B. vireti [44], all of which are also represented in the present study.

Antibiotics are often produced naturally by bacteria, including the genus Bacillus, which produces a wide variety of antimicrobial compounds (lipopeptides, enzymes, and antibiotics). At the same time, many of these bacteria have developed genes that are resistant to the antibiotics that they themselves produce. Thus, these antibiotic-producing microorganisms and other bacteria with which they coexist are capable of acting as potential sources of resistance genes [45]. Additionally, environmental bacteria can also be the recipient and reservoir of selected AR genes in the clinical, veterinary, or agricultural production fields. Many authors have demonstrated that resistance to antibiotics of a clinical origin can be traceable to non-pathogenic environmental strains [46,47]. The latter could possibly come into contact with animal and/or human pathogens and end up causing a public health problem $[48,49]$.

The interpretation of MIC for environmental isolates is complicated since many of them are non-pathogenic strains. However, MIC breakpoint interpretation for a large group of antibiotics for non-anthracis Bacillus spp. can be extrapolated the genus level using the CLSI M45-P document as a reference [40]. The Vitek ${ }^{\circledR} 2$ system was used to carry out antibiograms. The automation of this method allows an objective measurement system to obtain the MIC. For the interpretation of MIC values, CLSI does not have disk diffusion criteria for Bacillus spp. However, breakpoints are available in the document M100-s16 for $B$. anthracis against penicillin, tetracyclines, and ciprofloxacin [50]. Rare cases of resistance to the two latter antibiotics in Bacillus spp. justifies the defining of "susceptible" breakpoints. EUCAST offers criteria for the interpretation of levofloxacin, vancomycin, erythromycin, and clindamycin breakpoints [51]. 
From the set of analyzed strains, 33 belonged to antibiotypes I and $\mathrm{Ib}$ and were resistant to both ampicillin and benzylpenicillin. This finding has been widely reported by authors who have suggested that AR genes in numerous species of the Bacillus genus are ancient, very widespread, and could be selected by other edaphic species [41]. Less common is the presence of AR to cephalosporins in Bacillus spp. strains. However, resistance mechanisms mediated by $\beta$-lactamases that confer this phenotype have been described [52]. However, we found that 38 isolates were resistant to cefotaxime and intermediate to ceftriaxone (antibiotypes I, Ib, and IV), which could indicate that AR to cephalosporins in contaminated environments is more common than previously estimated. By contrast, antibiotypes II and III, which hardly present AR phenotypes, were less detected. Notably, wild-type bacteria are in the minority in this type of environment that is heavily polluted by $\mathrm{Hg}$. For this reason, the present study aimed to discover whether the presence of $\mathrm{Hg}$ in contaminated soil promotes and fosters the selection of AR mechanisms.

Long-term and persistent heavy metal contamination affects the microbial composition of soils in favor of microbial populations that are better adapted to stress situations, and that are more competitive from an ecological point of view [53]. One way to analyze the impact of this abiotic stress is by studying variations in the community structure and its diversity. The results of the Shannon-Wiener index in this work show a greater diversity in rhizospheric samples than in bulk soils. It is known that plants recruit the bacteria that inhabit the soil around their roots, providing a nutrient-rich microenvironment that favors certain bacterial communities to thrive or aid metal tolerance [54]. Another factor considered for the selection of Bacillus spp. strains for the successive analyses was the representativeness between samples. In view of the results and given that the quotient tended toward $100 \%$ in the rhizospheric samples, it was concluded that the diversity of the analyzed strains was close to the Hmax expected. This suggests a representativeness of the analyzed samples, eliminating factors that could alter it, such as uneven recruitment of rhizospheric microorganisms by the plant or a different accumulation of $\mathrm{Hg}$ in its environment that could modify the distribution of species. It is interesting that in bulk soil, where diversity was lower, $90 \%$ of the isolates belonged to "antibiotype I" (Figure 3). Rhizospheric samples, on the other hand, characterized by greater microbial diversity, presented a wider variety of antibiotypes, which could mean that the rhizosphere favors the colonization of bacteria with more heterogeneous AR profiles.

$\mathrm{Hg}$ resistance values registered in our strains ranged from 75 to $200 \mathrm{ppm}$. These concentrations are similar to those described by other authors [45]. It is interesting to see that the highest $\mathrm{Hg}$ MBCs are found in the strains of antibiotypes I, Ib, and IV. These antibiotypes are the only ones that are resistant to cephalosporins. The statistical analysis of correlation between $\mathrm{Hg} \mathrm{MBC}$ and MIC of cefotaxime and ceftriaxone was significant ( $p$-value $\leq 0.05)$. This analysis supports the hypothesis of simultaneous selection of genes for $\mathrm{Hg}$ resistance and genes for $\beta$-lactamases [19].

The increase in tetracycline resistance is also a serious problem for the clinical treatment of infectious diseases. Therefore, the transmissibility of AR genes is a subject of great scientific interest. Some authors have also observed high levels of AR to tetracyclines in edaphic Bacillus spp. strains [55]. Although this phenotype is unusual in the strains of the study herein, the four isolates included in antibiotype Ib showed tetracycline resistance. Traditionally, resistance to tetracyclines in Bacillus spp. has been linked to the presence of tet genes. These genes are found in a variety of bacteria isolated from humans, animals, and the environment and are typically located on the chromosome, plasmids, and transposons [56]. The mobile nature of these tetracycline-resistance genes may explain their wide distribution both in Gram negatives and Gram positives [57]. Of all the tet genes, the tet $L$ gene is most commonly found in Bacillus plasmids and is the second most prevalent tetracycline-resistant gene in streptococci and enterococci [58]. In their research involving contaminated sediment, Rassmussen and Sørensen [59] found that high levels of AR, at least to tetracycline in environments with high $\mathrm{Hg}$ contamination, could be due to the transfer of conjugative plasmids, thus providing indirect evidence of co-resistance. In con- 
cordance with these authors, the statistical analysis of the study herein revealed a positive co-selection of resistance to tetracycline and $\mathrm{Hg}$ in all of our strains ( $p$-value $\leq 0.05$ ).

The interpretation of the significant covariation values between $\mathrm{Hg} \mathrm{MBC}$ and tetracyclines and cephalosporins MICs agrees with other authors who stated that the HMR and AR genes are co-selected, conferring antibiotic-metal co-resistance [60]. Specifically, the genetic link of $\mathrm{Hg}$ resistance and AR in plasmids was demonstrated in bacteria by Summers et al. [61]. The high $\mathrm{Hg}$ pressure to which the analyzed soils and strains have been exposed has its origin in mining since Roman times. The findings of the present research coincide with Ji et al. [62], who suggested that metals such as $\mathrm{Hg}$, $\mathrm{Cu}$, and $\mathrm{Zn}$ may exert selective pressure for long-term AR genes.

\section{Conclusions}

1. Most of the mercurotolerant isolates of the Bacillus spp. genus are multi-resistant. Only antibiotypes II $(n=9)$ and III $(n=6)$, poorly represented, presented a resistance profile similar to the wild-type phenotype.

2. Of the 53 strains tested, 38 expressed a phenotype of resistance to cephalosporins. This finding suggests that the incidence of bacterial resistance to these antibiotics in $\mathrm{Hg}$-contaminated soils is higher than estimated in previous works.

3. The correlation between the $\mathrm{Hg}$ minimum bactericidal concentration (CMB) and the CMI of cefotaxime, ceftazidime, and tetracycline MIC was significant ( $p$-value $\leq 0.05$ ). This finding statistically demonstrates the co-selection of bacterial resistance to cephalosporins and tetracyclines under $\mathrm{Hg}$-selective environmental pressure.

Author Contributions: Conceptualization, M.R., A.P. and P.A.J.; methodology, M.R., A.P., D.G. and P.A.J.; software, M.R.; validation, M.R.; formal analysis, M.R., A.P. and P.A.J.; investigation, M.R. and D.G.; resources, A.P. and P.A.J.; data curation, A.P.; writing-original draft preparation, M.R. and P.A.J..; writing-review and editing, M.R., A.P. and P.A.J.; visualization, M.R.; supervision, A.P. and P.A.J.; project administration, A.P.; funding acquisition, A.P. and P.A.J. All authors have read and agreed to the published version of the manuscript.

Funding: This research has been funded by Fundación Universitaria San Pablo CEU and Banco Santander, grant number FUSP-BS-PPC01/2014.

Institutional Review Board Statement: Not applicable.

Informed Consent Statement: Not applicable.

Data Availability Statement: No new data were created or analyzed in this study. Data sharing is not applicable to this article.

Conflicts of Interest: The authors declare no conflict of interest.

\section{References}

1. Canteón, R. Antibiotic resistance genes from the environment: A perspective through newly identified antibiotic resistance mechanisms in the clinical setting. Clin. Microbiol. Infect. 2009, 15, 20-25. [CrossRef]

2. Martinez, J.L. Environmental pollution by antibiotics and by antibiotic resistance determinants. Environ. Pollut. 2009, 157, 2893-2902. [CrossRef]

3. Wright, G.D. Antibiotic resistance in the environment: A link to the clinic? Curr. Opin. Microbiol. 2010, 13, 589-594. [CrossRef]

4. Berendonk, T.U.; Manaia, C.M.; Merlin, C.; Fatta-Kassinos, D.; Cytryn, E.; Walsh, F.; Buergmann, H.; Sørum, H.; Norström, M.; Pons, M.-N.; et al. Tackling antibiotic resistance: The environmental framework. Nat. Rev. Microbiol. 2015, 13, 310-317. [CrossRef]

5. Martinez, J.L. The role of natural environments in the evolution of resistance traits in pathogenic bacteria. Proc. R. Soc. B Boil. Sci. 2009, 276, 2521-2530. [CrossRef]

6. D'Costa, V.M.; McGrann, K.M.; Hughes, D.W.; Wright, G.D. Sampling the Antibiotic Resistome. Science 2006, $311,374-377$. [CrossRef] [PubMed]

7. World Health Organization (WHO). Global Action Plan on Antimicrobial Resistance. 2015. Available online: https://apps.who. int/iris/handle/10665/193736 (accessed on 10 July 2021).

8. Chen, J.; Li, J.; Zhang, H.; Shi, W.; Liu, Y. Bacterial Heavy-Metal and Antibiotic Resistance Genes in a Copper Tailing Dam Area in Northern China. Front. Microbiol. 2019, 10, 1916. [CrossRef] [PubMed] 
9. Baldi, F.; Marchetto, D.; Gallo, M.; Fani, R.; Maida, I.; Covelli, S.; Fajon, V.; Žižek, S.; Hines, M.; Horvat, M. Chlor-alkali plant contamination of Aussa River sediments induced a large Hg-resistant bacterial community. Estuar. Coast. Shelf Sci. 2012, 113, 96-104. [CrossRef]

10. Ballabio, C.; Jiskra, M.; Osterwalder, S.; Borrelli, P.; Montanarella, L.; Panagos, P. A spatial assessment of mercury content in the European Union topsoil. Sci. Total Environ. 2021, 769, 144755. [CrossRef] [PubMed]

11. Wohlgemuth, L.; Osterwalder, S.; Joseph, C.; Kahmen, A.; Hoch, G.; Alewell, C.; Jiskra, M. A bottom-up quantification of foliar mercury uptake fluxes across Europe. Biogeosciences 2020, 17, 6441-6456. [CrossRef]

12. Gil-Hernández, F.; Gómez-Fernández, A.R.; La Torre-Aguilar, M.J.; Pérez-Navero, J.L.; Flores-Rojas, K.; Martín-Borreguero, P.; Gil-Campos, M. Neurotoxicity by mercury is not associated with autism spectrum disorders in Spanish children. Ital. J. Pediatr. 2020, 46, 1-7. [CrossRef]

13. Das, S.; Dash, H.R.; Chakraborty, J. Genetic basis and importance of metal resistant genes in bacteria for bioremediation of contaminated environments with toxic metal pollutants. Appl. Microbiol. Biotechnol. 2016, 100, 2967-2984. [CrossRef]

14. United Nations Environment Assembly. Minamata Convention on Mercury. Collection, UN Treaty. 2013. Available online: http:/ / www.mercuryconvention.org/Convention/Text (accessed on 10 July 2021).

15. Levy, S.B.; Marshall, B. Antibacterial resistance worldwide: Causes, challenges and responses. Nat. Med. 2004, 10, S122-S129. [CrossRef]

16. Huerta, B.; Marti, E.; Gros, M.; López, P.; Pompêo, M.; Armengol, J.; Barceló, D.; Balcazar, J.L.; Rodriguez-Mozaz, S.; Marcé, R. Exploring the links between antibiotic occurrence, antibiotic resistance, and bacterial communities in water supply reservoirs. Sci. Total Environ. 2013, 456, 161-170. [CrossRef] [PubMed]

17. Knapp, C.W.; Callan, A.; Aitken, B.; Shearn, R.; Koenders, A.; Hinwood, A. Relationship between antibiotic resistance genes and metals in residential soil samples from Western Australia. Environ. Sci. Pollut. Res. 2017, 24, 2484-2494. [CrossRef] [PubMed]

18. Tan, L.; Li, L.; Ashbolt, N.; Wang, X.; Cui, Y.; Zhu, X.; Xu, Y.; Yang, Y.; Mao, D.; Luo, Y. Arctic antibiotic resistance gene contamination, a result of anthropogenic activities and natural origin. Sci. Total Environ. 2018, 621, 1176-1184. [CrossRef] [PubMed]

19. Timoney, J.F.; Port, J.; Giles, J.; Spanier, J. Heavy-Metal and Antibiotic Resistance in the Bacterial Flora of Sediments of New York Bight. Appl. Environ. Microbiol. 1978, 36, 465-472. [CrossRef]

20. Seiler, C.; Berendonk, T.U. Heavy metal driven co-selection of antibiotic resistance in soil and water bodies impacted by agriculture and aquaculture. Front. Microbiol. 2012, 3, 399. [CrossRef]

21. Pal, C.; Bengtsson-Palme, J.; Kristiansson, E.; Larsson, D.G.J. Co-occurrence of resistance genes to antibiotics, biocides and metals reveals novel insights into their co-selection potential. BMC Genom. 2015, 16, 1-14. [CrossRef]

22. Nemergut, D.R.; Martin, A.P.; Schmidt, S.K. Integron Diversity in Heavy-Metal-Contaminated Mine Tailings and Inferences about Integron Evolution. Appl. Environ. Microbiol. 2004, 70, 1160-1168. [CrossRef] [PubMed]

23. Stepanauskas, R.; Glenn, T.; Jagoe, C.H.; Tuckfield, R.C.; Lindell, A.H.; King, C.J.; McArthur, J.V. Coselection for microbial resistance to metals and antibiotics in freshwater microcosms. Environ. Microbiol. 2006, 8, 1510-1514. [CrossRef] [PubMed]

24. Hu, H.; Wang, J.; Li, J.; Li, J.; Ma, Y.; Chen, D.; He, J. Field-based evidence for copper contamination induced changes of antibiotic resistance in agricultural soils. Environ. Microbiol. 2016, 18, 3896-3909. [CrossRef]

25. Di Cesare, A.; Eckert, E.; D’Urso, S.; Bertoni, R.; Gillan, D.C.; Wattiez, R.; Corno, G. Co-occurrence of integrase 1, antibiotic and heavy metal resistance genes in municipal wastewater treatment plants. Water Res. 2016, 94, 208-214. [CrossRef]

26. Wright, M.S.; Peltier, G.L.; Stepanauskas, R.; McArthur, J.V. Bacterial tolerances to metals and antibiotics in metal-contaminated and reference streams. FEMS Microbiol. Ecol. 2006, 58, 293-302. [CrossRef]

27. Monier, J.-M.; Demaneche, S.; Delmont, T.; Mathieu, A.; Vogel, T.; Simonet, P. Metagenomic exploration of antibiotic resistance in soil. Curr. Opin. Microbiol. 2011, 14, 229-235. [CrossRef]

28. Nesme, J.; Simonet, P. The soil resistome: A critical review on antibiotic resistance origins, ecology and dissemination potential in telluric bacteria. Environ. Microbiol. 2015, 17, 913-930. [CrossRef]

29. Wright, G.D. The antibiotic resistome: The nexus of chemical and genetic diversity. Nat. Rev. Genet. 2007, 5, 175-186. [CrossRef] [PubMed]

30. Forsberg, K.; Reyes, A.; Wang, B.; Selleck, E.; Sommer, M.O.A.; Dantas, G. The Shared Antibiotic Resistome of Soil Bacteria and Human Pathogens. Science 2012, 337, 1107-1111. [CrossRef]

31. Delgado-Baquerizo, M.; Guerra, C.A.; Cano-Díaz, C.; Egidi, E.; Wang, J.-T.; Eisenhauer, N.; Singh, B.K.; Maestre, F.T. The proportion of soil-borne pathogens increases with warming at the global scale. Nat. Clim. Chang. 2020, 10, 550-554. [CrossRef]

32. Domínguez-Begines, J.; Ávila, J.M.; García, L.V.; Gómez-Aparicio, L. Soil-borne pathogens as determinants of regeneration patterns at community level in Mediterranean forests. New Phytol. 2020, 227, 588-600. [CrossRef]

33. Millán, R.; Carpena, R.O.; Schmid, T.; Sierra, M.J.; Moreno, E.; Peñalosa, J.; Gamarra, R.; Esteban, E. Rehabilitación de suelos contaminados con mercurio: Estrategias aplicables en el área de Almadén. Ecosistemas 2007, 16, 56-66.

34. Velasco, A.G.-V.; Probanza, A.; Gutierrez-Mañero, F.J.; Ramos, B.; Garcia, J.A.L. Functional diversity of rhizosphere microorganisms from different genotypes of Arabidopsis thaliana. Community Ecol. 2009, 10, 111-119. [CrossRef]

35. Mathema, V.B.; Thakuri, B.K.C.; Sillanpää, M.; Shrestha, R.A. Study of mercury (II) tolerant bacterial isolates from Baghmati River with estimation of plasmid size and growth variation for the high mercury (II) resistant Enterobacter spp. J. Biotechnol. Res. 2011, 3, 72-77.

36. Weisburg, W.G.; Barns, S.M.; Pelletier, D.A.; Lane, D.J. $16 \mathrm{~S}$ ribosomal DNA amplification for phylogenetic study. J. Bacteriol. 1991, 173, 697-703. [CrossRef] 
37. Sanger, F.; Nicklen, S.; Coulson, A.R. DNA sequencing with chain-terminating inhibitors. Proc. Natl. Acad. Sci. USA 1977, 74, 5463-5467. [CrossRef] [PubMed]

38. Shannon, C.E.; Weaver, W. The Mathematical Theory of Communication; The University of Illinois Press: Urbana, IL, USA, 1949.

39. Pielou, E.C. An Introduction to Mathematical Ecology; Wiley: Hoboken, NJ, USA, 1969; 285p.

40. Clinical and Laboratory Standards Institute. Methods for Antimicrobial Dilution and Disk Susceptibility Testing of Infrequently Isolated or Fastidious Bacteria: Proposed Guideline M45-P, 3rd ed.; CLSI: Wayne, PA, USA, 2016.

41. Schlegelová, J.; Brychta, J.; Klimova, E.; Nápravníková, E.; Babak, V. The prevalence of and resistance to antimicrobial agents of Bacillus cereus isolates from foodstuffs. Veterinární Med. 2012, 48, 331-338. [CrossRef]

42. Narita, M.; Chiba, K.; Nishizawa, H.; Ishii, H.; Huang, C.-C.; Kawabata, Z.; Silver, S.; Endo, G. Diversity of mercury resistance determinants among Bacilluss trains isolated from sediment of Minamata Bay. FEMS Microbiol. Lett. 2003, 223, 73-82. [CrossRef]

43. Garbeva, P.; Van Veen, J.; Van Elsas, J. Predominant Bacillus spp. in Agricultural Soil under Different Management Regimes Detected via PCR-DGGE. Microb. Ecol. 2003, 45, 302-316. [CrossRef]

44. Bartelt-Hunt, S.; Snow, D.; Damon-Powell, T.; Miesbach, D. Occurrence of steroid hormones and antibiotics in shallow groundwater impacted by livestock waste control facilities. J. Contam. Hydrol. 2011, 123, 94-103. [CrossRef]

45. Heuer, H.; Schmitt, H.; Smalla, K. Antibiotic resistance gene spread due to manure application on agricultural fields. Curr. Opin. Microbiol. 2011, 14, 236-243. [CrossRef]

46. Benveniste, R.; Davies, J. Aminoglycoside Antibiotic-Inactivating Enzymes in Actinomycetes Similar to Those Present in Clinical Isolates of Antibiotic-Resistant Bacteria. Proc. Natl. Acad. Sci. USA 1973, 70, 2276-2280. [CrossRef]

47. D'Costa, V.M.; Griffiths, E.; Wright, G. Expanding the soil antibiotic resistome: Exploring environmental diversity. Curr. Opin. Microbiol. 2007, 10, 481-489. [CrossRef]

48. Witte, W. Ecological impact of antibiotic use in animals on different complex microflora: Environment. Int. J. Antimicrob. Agents 2000, 14, 321-325. [CrossRef]

49. CLSI. Performance Standards for Antimicrobial Susceptibility Testing: Sixteenth Informational Supplement M100-S16; CLSI: Wayne, PA, USA, 2020.

50. The European Committee on Antimicrobial Susceptibility Testing. Breakpoint tables for interpretation of MICs and zone diameters, version 11.0. 2021.

51. Bucher, T.; Keren-Paz, A.; Hausser, J.; Olender, T.; Cytryn, E.; Kolodkin-Gal, I. An active $\beta$-lactamase is a part of an orchestrated cell wall stress resistance network of Bacillus subtilis and related rhizosphere species. Environ. Microbiol. 2019, 21, 1068-1085. [CrossRef]

52. Kong, X.-X.; Jiang, J.-L.; Qiao, B.; Liu, H.; Cheng, J.-S.; Yuan, Y.-J. The biodegradation of cefuroxime, cefotaxime and cefpirome by the synthetic consortium with probiotic Bacillus clausii and investigation of their potential biodegradation pathways. Sci. Total Environ. 2019, 651, 271-280. [CrossRef]

53. Abdu, N.; Abdullahi, A.A.; Abdulkadir, A. Heavy metals and soil microbes. Environ. Chem. Lett. 2017, 15, 65-84. [CrossRef]

54. Borymski, S.; Cycoń, M.; Beckmann, M.; Mur, L.; Piotrowska-Seget, Z. Plant Species and Heavy Metals Affect Biodiversity of Microbial Communities Associated with Metal-Tolerant Plants in Metalliferous Soils. Front. Microbiol. 2018, 9, 1425. [CrossRef] [PubMed]

55. Chelliah, R.; Wei, S.; Park, B.-J.; Park, J.-H.; Park, Y.-S.; Kim, S.-H.; Jin, Y.-G.; Oh, D.-H. New perspectives on Mega plasmid sequence (poh1) in Bacillus thuringiensis ATCC 10792 harbouring antimicrobial, insecticidal and antibiotic resistance genes. Microb. Pathog. 2019, 126, 14-18. [CrossRef]

56. Roberts, M.C. Epidemiology of tetracycline-resistance determinants. Trends Microbiol. 1994, 2, 353-357. [CrossRef]

57. Chopra, I.; Roberts, M. Tetracycline Antibiotics: Mode of Action, Applications, Molecular Biology, and Epidemiology of Bacterial Resistance. Microbiol. Mol. Biol. Rev. 2001, 65, 232-260. [CrossRef] [PubMed]

58. Michalova, E.; Novotna, P.; Schlegelová, J. Tetracyclines in veterinary medicine and bacterial resistance to them. Veterinární Med. 2012, 49, 79-100. [CrossRef]

59. Rasmussen, L.D.; Sørensen, S. The Effect of Longterm Exposure to Mercury on the Bacterial Community in Marine Sediment. Curr. Microbiol. 1998, 36, 291-297. [CrossRef] [PubMed]

60. Foster, T.J. Plasmid-determined resistance to antimicrobial drugs and toxic metal ions in bacteria. Microbiol. Rev. 1983, 47, 361-409. [CrossRef] [PubMed]

61. Summers, A.; Wireman, J.; Vimy, M.J.; Lorscheider, F.L.; Marshall, B.; Levy, S.B.; Bennett, S.; Billard, L. Mercury released from dental "silver" fillings provokes an increase in mercury- and antibiotic-resistant bacteria in oral and intestinal floras of primates. Antimicrob. Agents Chemother. 1993, 37, 825-834. [CrossRef]

62. Ji, L.; Xie, S.; Feng, J.; Li, Y.; Chen, L. Heavy metal uptake capacities by the common freshwater green alga Cladophora fracta. Environ. Boil. Fishes 2011, 24, 979-983. [CrossRef] 